\title{
THE CONSTRUCTION AND EVALUATION OF AN ATTENTION QUESTIONNAIRE
}

\author{
JOHANN M SCHEPERS \\ annetjieb@uj.ac.za \\ Department of Human Resource Management \\ University of Johannesburg
}

\begin{abstract}
The principal objective of the study was the construction and evaluation of an attention questionnaire. A corollary of the study was to determine the common factors between the Attention Questionnaire (AQ) and the Locus of Control Inventory (LCI).

The AQ and the LCI (1999) were applied jointly to a sample of 1577 first-year university students. To start with the $\mathrm{AQ}$ was subjected to a principal factor analysis. It yielded three factors which were identified as Concentration Ability, Arousal and Distractibility. Three scales were formed which yielded reliabilities of 0,886, 0,757 and 0,863 respectively.

Multiple battery factor analysis was used to establish the common factor structure of the two instruments. Autonomy and Internal Control were strongly related to Concentration Ability.
\end{abstract}

Keywords:

Concentration Ability, arousal, distractibility, autonomy, internal control, external control

As human beings we are constantly exposed to a myriad of stimuli coming from the external environment as well as from within our bodies. But, unless we pay attention to particular stimuli (selective attention), the information conveyed by them will not be processed by us. According to Davidoff (1987, p.130) "our attentional style has survival value. It helps us allocate our resources in an advantageous way. We attend minimally to routine, regularly occurring events. We attend maximally to messages that cannot safely be ignored. If we attended at once to everything, critical cues could be lost amid the clutter".

Selective attention, or the ability to focus attention, is of critical importance in the work situation where persons must perform certain tasks in the presence of many distracting stimuli. They must necessarily distinguish between relevant and irrelevant stimuli and must act only on the relevant ones (Howard, 1983). Ignoring irrelevant stimuli is of critical importance in situations where the task requires the operator to focus on certain defining attributes of the display of sensory information. The ability to focus attention or concentrate is particularly important in jobs where vigilance is a prerequisite (Harkins \& Geen, 1975; Rusinova, 1990). In performing their jobs sonar and radar operators, air traffic controllers and nuclear plant operators have to remain vigilant for long periods of time and be cautious not to miss any signals.

Vigilance appears to be associated with introversion-extraversion (Eysenck, 1967). Harkins and Geen (1975) have shown that in a signal detection task introverts detected more signals $(\mathrm{M}=0,76)$ than did extraverts $(M=0,46)[F(2,36)=9,7, p<0,05]$, and extraverts made more false alarms $(\mathrm{M}=0,19)$ than did introverts $(\mathrm{M}=0,03)[\mathrm{F}(1,18)=28,1, \mathrm{p}<0,05]$ (p. 337).

Damrad-Frye and Laird (1989, pp. 317-319) found that introverts and extraverts differed from one another depending on the amount of distraction present in the experimental situation. Three conditions of distraction were used, viz. no-distraction, moderate-distraction, and loud-distraction.

In the moderate-distraction situation introverts rated themselves as significantly more bored than in the other two conditions $[\mathrm{F}(2$, $73)=4,90, p<0,01)$ (p. 318). For extraverts little difference was found between the no-distraction situation and the moderatedistraction situation. However, in the loud-distraction situation they rated themselves as significantly more bored than in the other two conditions $[F(2,73)=3,80, p<0,031]$ (p. 318).

From the above-mentioned findings Damrad-Frye et al. (1989) concluded that "extraverts are less distractible than introverts and, therefore, were unaffected by the moderate level of distraction (p. 318). "Extraverts get bored more quickly than introverts with monotomous tasks because they need higher levels of stimulation" (p. 317).

Selective attention and vigilance are strongly associated with certain dispositional variables. It is therefore imperative that appropriate measuring devices be constructed to determine the interrelationships between the various constructs.

According to Picton, Campbell, Baribeau-Braun and Proulx (1978, p. 446) the most reasonable hypothesis about human attention is "that there is an initial registration and analysis of sensory information occurring prior to and independently of attentional selection. Attention has its most definite neurophysiological correlates in the evoked potential components that occur later than $50 \mathrm{~m} \mathrm{sec}$ after stimulus onset". "When attention is directed towards a particular sensory channel, there is enhancement of a negative component in the evoked potential with a peak latency of around $100 \mathrm{~m}$ sec $-N_{\overline{100}}$. This effect is based on the simple stimulus attributes that define the selected channel, and it occurs irrespective of the significance of the stimuli within that channel" (p. 429). "The evoked potential to an important signal or target stimulus within an attended channel contains, as well as the enhanced $\mathrm{N}_{\overline{100}}$ component, a large positive wave with a peak latency of near $350 \mathrm{~m}$ sec $-P_{350}$ " (p. 429). The process of selective attention can thus be studied by means of the eventrelated potentials of the brain.

Schafer (1982), working in the field of evoked potentials (EPs) of the brain, hypothesised that "people showing high neural adaptability, characterized by the production of EPs with much smaller than average amplitude to expected stimuli and much larger than average amplitude to unexpected stimuli, should show high behavioural intelligence. Conversely, people of low cognitive capacity, such as those classified as "mentally retarded", should show deficits in neural adaptability" (p. 184).

To test the above hypothesis Schafer (1982, pp. 184-186) recorded the auditory evoked potentials from the vertex of 109 normal and 52 mentally retarded adults under three conditions of stimulation. The conditions of stimulation were designed to manipulate temporal expectancy (periodic, self, and random).

It was found that the normal subjects gave a significantly smaller (24\%) than average EP to self-delivered stimuli $(t=12,04$; $d f=$ 108; $\mathrm{p}<0,001)$, indicating a definite temporal expectancy effect 
on their brain responses (p. 186). In contrast, the retarded adults showed no significant difference between their self and average amplitude $(\mathrm{t}=1,13 ; \mathrm{df}=51 ; \mathrm{p}>0,05)$, indicating a definite deficit in neural adaptability (p. 186).

As far as the random stimulation condition is concerned the normal adults gave a significantly larger than average EP (25\%) to unexpected, randomly delivered stimuli $(\mathrm{t}=12,58 ; \mathrm{df}=108$; $\mathrm{p}<0,001)$. In contrast, the retarded adults only showed a $14 \%$ difference between their random and average EP values $(t=7,57$; $\mathrm{df}=51 ; \mathrm{p}<0,001)$. The normal adults thus oriented much more vigorously to unexpected inputs than did the retarded adults (p. 186). Using a subsample of 74, for whom IQs were available, the random/average EP amplitude ratio was correlated with the WAIS full scale IQ. A correlation of $0,65(p<0,01)$ was obtained (p. 186).

Schepers, Stuart and Todd (1999) investigated the relationship between the evoked potential of the brain and psychometric intelligence. They studied a sample of 125 first-year women students, because it had been found that spuriously high or low correlations are obtained if genders and age groups are mixed (Eysenck \& Barrett, 1985). The sample was drawn in such a way that it conformed to a normal distribution with a definite point of truncation (95 IQ) (Schepers et al., 1999, pp. 139-140).

The psychometric test battery consisted of four tests, namely the General Scholastic Aptitude Test, the Pattern Relations Test, the Gottschaldt Figures Test and the Mental Alertness Test of the High Level Battery.

The neurophysiological battery consisted of two main procedures, namely "the auditory evoked potential and the pattern-reversal visual evoked potential" (Schepers et al., 1999, p. 140).

As far as the psychometric measures of intelligence are concerned two indices were formed, namely Non-verbal Intelligence and Verbal Intelligence. A multiple correlation of 0,55 (corrected for restriction of range) was found between the neurophysiological measures and the index of Non-verbal Intelligence. A multiple correlation of 0,60 (corrected for restriction of range) was obtained between the neurophysiological measures and the Verbal index of Intelligence. There is thus a strong association between neural adaptability and psychometric intelligence.

From the foregoing it should be clear that selective attention and vigilance are intimately associated with the cognitive make-up of persons and certain of their personality characteristics.

Diehl, Semegon and Schwarzer (2006) studied the ability of young adults $(\mathrm{N}=443)$ to control their attention in goal-directed behaviour. They defined attention control as "a person's ability to focus his or her attention on a given task, to control and regulate external and internal distractions, and to work toward a desired goal or outcome" (p. 306). They used the SelfRegulation Scale (SRS) of Schwarzer, Diehl and Schmitz (1999), and the Generalized Self-Efficacy Scale (GSES) of Schwarzer and Jerusalem (1995); the Academic Self-Evaluation Scale (ASES) of Wood and Locke (1987), and the Proactive Coping Inventory (PCS) of Greenglass (2002).

As a first step in their investigation Diehl et al. (2006) estimated the reliability of the SRS for their sample of young adults. A Cronbach alpha coefficient of 0,76 was obtained. Test-retest reliability after six weeks with a subsample of 239 participants yielded a correlation of $0,62(p<0,001)$ (p. 310). These coefficients are somewhat disappointing, but are probably due to the shortness of the scale (10 items). It is a self-report inventory and was designed to measure the degree of self-control a person has over his/her thoughts and emotions, and over distracting stimuli.

In a second study with a more heterogeneous sample as far as age is concerned, the SRS yielded a Cronbach alpha coefficient of 0,84 . The ages of this sample ranged from 19 to 87 years (pp. 311-313).

To assess the criterion validity of the SRS Diehl et al. correlated the scale with the PCS, GSES and ASES (2006, p. 310). Attention control correlated $0,55,0,58$ and 0,21 with the respective scales. Furthermore, attention control, proactive coping, general selfefficacy and academic self-efficacy were positively associated with one another. All the correlations were statistically significant at $\mathrm{p} \leq 0,01$ (cf. Table 1, p. 310).

Despite the fact that the SRS yielded some interesting results, it has several shortcomings: From a content validity point of view the scale is very limited, nothing is known about its construct validity, and its reliability is borderline for young adults. Many more items need to be written, and the factor structure of the extended version needs to be established. The reliability of each of the constructs that emerge needs to be determined. The item format used is in the form of positively and negatively directed statements and this probably leads to acquiescence.

Schepers (1992) designed a self-report inventory of attention, called the Attention Questionnaire. It consisted of 54 items dealing essentially with concentration ability. All the items were in the form of questions, and the responses had to be endorsed on a seven-point scale. It was applied to a representative sample of 424 first-year students in the Faculty of Economic and Management Sciences at the Rand Afrikaans University and yielded a Cronbach alpha reliability coefficient of 0,886 (De W Vos \& Schepers, 1993, p. 26).

To investigate the convergent validity of the AQ two contrasting groups were formed by dividing the score distribution of the sample into three sections. The middle section (approximately $38 \%$ ) was then removed and the lowest and highest sections were retained. The Jung Personality Questionnaire (JPQ) (Du Toit, 1983), the Sixteen Personality Factor Questionnaire (16 PF) (Cattell, 1989), the Senior Aptitude Tests (SAT) (Fouché \& Verwey, 1978) and the New South African Group Test (NSAG) were then applied to the two groups (De W Vos \& Schepers, 1993, p. 25). The mean scores of the two groups were then compared in respect of the NSAG, the SAT, the $16 \mathrm{PF}$ and the JPQ. The vectors of means of the two contrasting groups were compared by means of the Hotelling-T ${ }^{2}$ test. It was found that the vectors of means of the two groups differed statistically significantly from one another in respect of both the cognitive and personality variables. The Hotelling- $\mathrm{T}^{2}$ in respect of the cognitive variables was as follows: [Hotelling- $\mathrm{T}^{2}(12,215)=39,887 ; \mathrm{F}=3,162$; $\mathrm{p}=0,0004]$ (p. 26).

The group with high scores on Concentration Ability (High Group) obtained significantly higher scores on the following tests than the group with low scores on Concentration Ability (Low Group):

- Verbal IQ,

- Non-verbal IQ,

- Pattern Completion,

- Figure Series,

- Verbal Comprehension,

- Calculations,

- Spatial 2-D,

- Spatial 3-D.

Concentration Ability is thus strongly associated with intelligence and cognitive ability.

The Hotelling- $\mathrm{T}^{2}$ in respect of the $16 \mathrm{PF}$ and the JPQ was as follows:

$\left[\right.$ Hotelling- $\left.\mathrm{T}^{2}(20,207)=129,385 ; \mathrm{F}=5,925 ; \mathrm{p}<0,0001\right]$ (p. 27).

The High Group obtained significantly higher scores on the following primary factors of the 16 PF than the Low Group:

- Factor C (Ego-strength): Emotionally stable, realistic, adaptable and self-controlled. 
- Factor E (Dominance): Self-assertive, competitive and independent.

- Factor G (Super-ego strength): Conscientious, persistent and rule-bound.

- Factor H (Socially Bold): Venturesome and socially bold.

- Factor N (Calculating): Socially alert, ambitious and shrewd.

- Factor Q1 (Experimenting): Liberal, analytical and freethinking.

- Factor Q3 (Positive self-concept): Strong selfsentiment, strong willpower, and socially self-controlled.

The High Group obtained lower scores on the following factors than the Low Group:

- Factor L (Trusting): Trusting and accepting of circumstances.

- Factor O (Unperturbed): Calm and peaceful.

- Factor Q4 (Relaxed): Calm, restful and relaxed.

As far as the JPQ is concerned the High Group obtained higher scores on Thinking-Feeling and Judging-Perceiving, and lower scores on Perception-Intuition, than the Low Group. The High Group thus has a personality type characterised by Thinking, Judging and Intuition.

From the foregoing it should be clear that concentration ability is intimately associated with intelligence, aptitude and personality. Persons who are high on concentration ability were found to be highly adaptable and emotionally mature. They have a positive self-concept, are realistic, and act in a responsible way (p. 28).

Control of attention, concentration ability, arousal and distractibility are of critical importance in jobs requiring alertness and vigilance (Barkhuizen, Schepers \& Coetzee, 2002). A sound measuring device of attention is therefore urgently required for use in selection and student counselling.

The Attention Questionnaire (AQ) of Schepers (1992) needs to be extended in order to measure concentration ability as well as arousal and distractibility. After extension of the scale its construct validity, convergent validity, and metrical properties will have to be determined afresh.

\section{Objectives of the study}

The principal objective of the present study was to extend and evaluate the AQ (1992) of Schepers. Its factor structure and metrical properties were determined afresh. A corollary of the study was to determine the common factors between the AQ and the Locus of Control Inventory (1999).

\section{RESEARCH DESIGN}

\section{Research approach}

A quantitative approach was followed in the analysis of the data. In particular principal factor analysis and multiple battery factor analysis was used. The data were collected by means of a field survey.

\section{Participants}

An extended version of the Attention Questionnaire (1999) together with the Locus of Control Inventory (LCI) were applied to 1577 first-year students at an Afrikaans University during 2000. The ages of the students ranged from 16 to 53 years, with a mean of 18,16 years and a standard deviation of 1,422 years. As far as gender is concerned $51,4 \%$ were female and $35,6 \%$ were male. Missing information accounted for $12,9 \%$. The majority of the students were English-speaking (728). Four hundred and thirty-two were Afrikaans-speaking, and 91 spoke both English and Afrikaans. Only 69 had an African language as vernacular. Fifty-three spoke other languages, and 204 did not indicate their home language. As far as ethnic group is concerned $72,8 \%$ were White, $6,3 \%$ were Indian, 2,8\% were Coloured and 5,1\% were Black. Missing information accounted for $12,9 \%$ of the cases.

\section{Measuring instruments}

The measuring instruments that were used in this study are the revised edition (1999) of the Attention Questionnaire (AQ) and the 1999 edition of the Locus of Control Inventory (LCI).

The 1992 version of the Attention Questionnaire (De W Vos \& Schepers, 1993, pp. 25-26) was revised and extended from 54 items to 72 items. It deals with those factors or circumstances that facilitate or inhibit attention, factors that distract attention or cause one's attention to wander, the ability to plan ahead, sustained attention or concentration, factors that reduce or inhibit a person's concentration ability, the duration of sustained attention, and the ability to divide one's attention.

As the 1999 edition of the LCI has been fully described by Schepers, Gropp and Geldenhuys (2006) no further detail about the inventory will be given here, suffice it to say that an appropriate manual for the test is available.

\section{Procedure}

The AQ and the LCI were applied jointly to the same sample of first-year university students in 2000. Complete records for both instruments were obtained in respect of 1288 participants.

\section{Statistical analysis}

To determine the common factors between the $\mathrm{AQ}$ and the LCI, multiple battery factor analysis (MBFA) was used. MBFA uses the cross-correlations between two or more test batteries and determines only the factors common to the test batteries (Browne, 1980; Cudeck, 1980, 1991; Schepers, 2006). It has the advantage over principal factor analysis that it can cope with moderate degrees of skewness of the variables involved (Schepers, 2004, p. 79).

To determine the metrical properties of the AQ an iterative item analysis program (NP50) was used. A full description of the procedure is given in Toetskonstruksie: Teorie en praktyk (Schepers, 1992, pp. 96-99). In the selection of items the program can either iterate on the item-test correlations or on the indices of reliability of the items. The index of reliability of an item is given by the item-test correlation multiplied with the standard deviation of the item. It is important to note that the item-test correlations must not be corrected for their part-whole effect as this will destroy the relationship of the indices of reliability with the test variance:

$$
\begin{aligned}
S_{x}^{2} & =\left(\sum_{g=1}^{K} r_{g} s_{g}\right)^{2}, \text { where } \\
S_{x}^{2} & =\text { test variance } \\
r_{g x} & =\text { item }- \text { test correlation } \\
S_{g} & =\text { items standard deviation } \\
K & =\text { number of items }
\end{aligned}
$$

The reliability of a test or scale can be maximised by maximising its variance:

$$
\text { Cronbach alpha }=\frac{K}{K-1}\left[1-\frac{\sum_{g=1}^{K} S_{g}^{2}}{S_{x}^{2}}\right]
$$

Where:

$K=$ number of items

$S_{g}^{2}=$ variance of item $g$

$S_{x}^{2}=$ test variance 
The above formula can also be written as follows:

$$
\begin{aligned}
\alpha & =\frac{K}{K-1}\left[1-\frac{1}{K}-\frac{\sum_{g=1}^{K} s_{g}^{2}}{s_{x}^{2}}+\frac{1}{K}\right] \\
& =\left[1-\frac{K \sum_{g=1}^{K} S_{g}^{2}-S_{x}^{2}}{(K-1) S_{x}^{2}}\right]
\end{aligned}
$$

The maximum variance of a test is given by $S_{x}^{2}=K \sum_{g=1}^{K} S_{g}^{2}$ (Schepers, 1992, p. 33). Therefore, $\left[K \sum_{g=1}^{K} S_{g}^{2}-S_{x}^{2}\right]$, in equation (3) will be a minimum if $S_{x}^{2}$ is a maximum (Schepers, 1992, p. 98). In this case Cronbach alpha will be a maximum. The reliability of a scale can therefore be maximised by iterating on the index of reliability of the items and rejecting the items with the lowest indices.

\section{RESULTS}

The items of the AQ were intercorrelated, and the eigenvalues of the intercorrelation matrix were calculated. Eighteen of the eigenvalues were greater than unity, accordingly 18 factors were extracted and rotated to simple structure by means of a Varimax rotation. These tables, however, are too large for reproduction here ${ }^{1}$.

Two of the factors had no meaningful loadings and were omitted from the rest of the analysis. Next, subscores were calculated in respect of the remaining 16 factors. The subscores were then intercorrelated and the intercorrelation matrix is given in Table 1.

From Table 1 it is clear that the various subscores are mutually correlated despite the fact that the initial factors were orthogonal to one another.

TABLE 1

\begin{tabular}{|c|c|c|c|c|c|c|c|c|}
\hline & Subscore 1 & Subscore 2 & Subscore 3 & Subscore 4 & Subscore 5 & Subscore 6 & Subscore 7 & Subscore 8 \\
\hline Subscore 1 & 1 & $-0,293$ * * & $-0,338^{* *}$ & $-0,236^{* *}$ & 0,271 * * & $0,193^{* *}$ & $0,495^{* *}$ & $0,060^{*}$ \\
\hline Subscore 2 & $-0,293 * *$ & 1 & $0,509 * *$ & 0,611 ** & $-0,378^{* *}$ & $-0,173^{* *}$ & $-0,414^{* *}$ & $-0,043$ \\
\hline Subscore 3 & $-0,338 * *$ & $0,509 * *$ & 1 & 0,457 * * & $-0,277$ * * & $-0,054^{*}$ & $-0,377 * *$ & $-0,055^{*}$ \\
\hline Subscore 4 & $-0,236^{* *}$ & 0,611 * * & 0,457 * * & 1 & $-0,298$ ** & $-0,123$ ** & $-0,336$ ** & $-0,037$ \\
\hline Subscore 5 & 0,271 * * & $-0,378$ ** & $-0,277$ * * & $-0,298$ * * & 1 & $0,211^{* *}$ & 0,383 * * & 0,101 * * \\
\hline Subscore 6 & 0,193 * * & $-0,173$ ** & $-0,054^{*}$ & $-0,123$ ** & $0,211^{* *}$ & 1 & 0,273 * * & 0,335 * * \\
\hline Subscore 7 & 0,495 * * & $-0,414$ ** & $-0,377$ * * & $-0,336^{* *}$ & 0,383 * * & 0,273 ** & 1 & $0,119 * *$ \\
\hline Subscore 8 & $0,060^{*}$ & $-0,043$ & $-0,055^{*}$ & $-0,037$ & 0,101 ** & $0,335^{* *}$ & $0,119^{* *}$ & 1 \\
\hline Subscore 9 & $0,152 * *$ & $-0,292 * *$ & $-0,130$ ** & $-0,251$ ** & $0,288 * *$ & 0,249 * * & 0,281 * * & 0,090 * * \\
\hline Subscore 10 & $-0,123$ ** & 0,127 * * & $0,136^{* *}$ & 0,132 * * & 0,005 & $0,056^{*}$ & $-0,115^{* *}$ & 0,044 \\
\hline Subscore 11 & $-0,061^{*}$ & 0,327 * * & $0,352^{* *}$ & $0,325^{* *}$ & $-0,091$ * * & 0,023 & $-0,129 * *$ & $0,061^{*}$ \\
\hline Subscore 12 & $-0,243$ ** & 0,363 * * & $0,336^{* *}$ & 0,279 * * & $-0,159$ ** & $-0,055^{*}$ & $-0,246^{* *}$ & 0,042 \\
\hline Subscore 13 & $-0,181$ ** & 0,260 ** & 0,379 * * & $0,234^{* *}$ & $-0,059^{*}$ & $-0,023$ & $-0,141$ ** & $-0,013$ \\
\hline Subscore 14 & $0,426 * *$ & $-0,086^{* *}$ & $-0,268 * *$ & $-0,125$ ** & 0,147 * * & $0,058^{*}$ & 0,208 * * & $-0,027$ \\
\hline Subscore 15 & 0,187 * * & $-0,187$ * * & $-0,202 * *$ & $-0,109$ * * & $0,105^{* *}$ & 0,251 * * & 0,203 * * & 0,221 * * \\
\hline Subscore 16 & 0,000 & 0,168 * * & 0,075 * * & $0,240 * *$ & $-0,056^{*}$ & $0,072 * *$ & $-0,041$ & $0,062^{*}$ \\
\hline
\end{tabular}

MATRIX OF INTERCORRELATIONS OF THE SUBSCORES OF THE ATTENTION QUESTIONNAIRE

Note.

**Correlation significant at 0,01 level (2-tailed)

*Correlation significant at 0,05 level (2-tailed)

\begin{tabular}{|c|c|c|c|c|c|c|c|}
\hline Subscore 9 & Subscore 10 & Subscore 11 & Subscore 12 & Subscore 13 & Subscore 14 & Subscore 15 & Subscore 16 \\
\hline 0,152 * * & $-0,123^{* *}$ & $-0,061$ * & $-0,243^{* *}$ & $-0,181^{* *}$ & $0,426^{* *}$ & 0,187 * * & 0,000 \\
\hline$-0,292$ * * & 0,127 * * & 0,327 * * & 0,363 ** & 0,260 ** & $-0,086^{* *}$ & $-0,187$ * * & 0,168 * * \\
\hline$-0,130$ * * & 0,136 * * & 0,352 * * & 0,336 * * & 0,379 * * & $-0,268^{* *}$ & $-0,202^{* *}$ & 0,075 * * \\
\hline$-0,251$ * * & 0,132 * * & 0,325 * * & 0,279 * * & 0,234 * * & $-0,125^{* *}$ & $-0,109$ * * & 0,240 ** \\
\hline $0,288^{* *}$ & 0,005 & $-0,091$ * * & $-0,159^{* *}$ & $-0,059^{*}$ & 0,147 * * & 0,105 * * & $-0,056^{*}$ \\
\hline 0,249 ** & $0,056^{*}$ & 0,023 & $-0,055^{*}$ & $-0,023$ & $0,058^{*}$ & $0,251 * *$ & $0,072 * *$ \\
\hline 0,281 * * & $-0,115$ ** & $-0,129$ ** & $-0,246^{* *}$ & $-0,141$ ** & 0,208 * * & 0,203 * * & $-0,041$ \\
\hline 0,090 ** & 0,044 & 0,061 * & 0,042 & $-0,013$ & $-0,027$ & 0,221 ** & $0,062^{*}$ \\
\hline 1 & $-0,076^{* *}$ & 0,000 & $-0,071^{* *}$ & 0,081 * * & 0,095 * * & $0,069 * *$ & $-0,012$ \\
\hline$-0,076^{* *}$ & 1 & 0,042 & 0,114 * * & 0,072 ** & $-0,084^{* *}$ & $-0,044$ & 0,081 * * \\
\hline 0,000 & 0,042 & 1 & 0,212 ** & 0,254 * * & $-0,053^{*}$ & $-0,062^{*}$ & 0,130 * * \\
\hline$-0,071^{* *}$ & 0,114 * * & $0,212 * *$ & 1 & 0,291 * * & $-0,130$ * * & $-0,095$ * * & 0,137 * * \\
\hline 0,081 * * & 0,072 * * & 0,254 * * & 0,291 * * & 1 & $-0,123$ ** & $-0,161$ * * & $0,146^{* *}$ \\
\hline 0,095 * * & $-0,084^{* *}$ & $-0,053^{*}$ & $-0,130^{* *}$ & $-0,123$ * * & 1 & 0,009 & $-0,043$ \\
\hline 0,069 ** & $-0,044$ & $-0,062^{*}$ & $-0,095$ * * & $-0,161$ ** & 0,009 & 1 & 0,047 \\
\hline$-0,012$ & 0,081 * * & 0,130 * * & 0,137 * * & $0,146^{* *}$ & $-0,043$ & 0,047 & 1 \\
\hline
\end{tabular}

$\mathrm{N}=1577$ 
The eigenvalues of the intercorrelation matrix of subscores are given in Table 2.

TABLE 2

EIGENVALUES OF UNREDUCED INTERCORRELATION MATRIX $(16 \times 16)$

\begin{tabular}{lccc}
\hline Root & Eigenvalue & $\begin{array}{c}\text { Percentage of } \\
\text { variance }\end{array}$ & $\begin{array}{c}\text { Cumulative } \\
\text { percentage }\end{array}$ \\
\hline 1 & 3,882 & 24,262 & 24,262 \\
2 & $\mathbf{1 , 7 7 6}$ & 11,103 & 35,365 \\
3 & $\mathbf{1 , 2 8 1}$ & 8,005 & 43,369 \\
4 & $\mathbf{1 , 2 3 0}$ & 7,685 & 51,055 \\
5 & 0,990 & 6,190 & 57,245 \\
6 & 0,913 & 5,705 & 62,950 \\
7 & 0,798 & 4,989 & 67,940 \\
8 & 0,739 & 4,620 & 72,560 \\
9 & 0,709 & 4,429 & 76,989 \\
10 & 0,667 & 4,168 & 81,157 \\
11 & 0,626 & 3,915 & 85,072 \\
12 & 0,613 & 3,828 & 88,900 \\
13 & 0,565 & 3,529 & 92,429 \\
14 & 0,455 & 2,846 & 95,275 \\
15 & 0,403 & 2,518 & 97,793 \\
16 & 0,353 & 2,207 & 100,000 \\
\hline Trace & 16,000 & 100,000 & \\
\hline
\end{tabular}

Table 2 shows that four of the eigenvalues are greater than unity. Accordingly four factors were extracted and rotated to simple structure by means of a Direct Oblimin rotation (Kaiser, 1961). However, only three of the factors were reasonably well determined. The fourth factor had only one significant loading $(0,529)$, representing four items. The issue of number of factors was further examined by preparing a Scree and Parallel Analysis plot. The resulting plots are given in Figure 1.

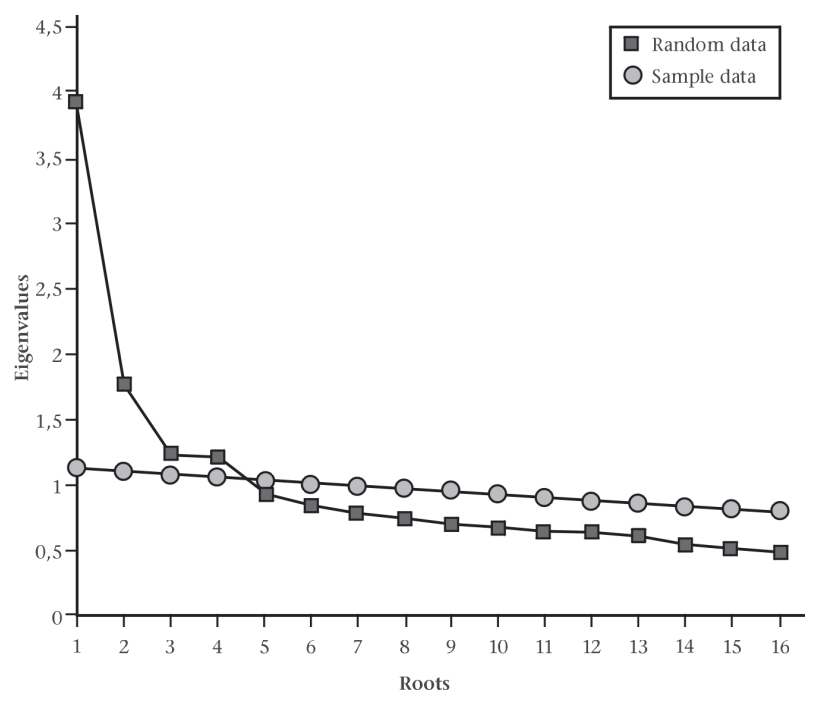

Figure 1: Scree and parallel analysis plot

From Figure 1 it is clear that the fourth root is barely above the plot of the random data. The four items $(61,63,69$ and 70), represented by the fourth factor, concern the effect of change and variety, humour, hostility, and rest pauses on the ability of a respondent to concentrate. If three factors are extracted these items move to Factor 2 (Arousal). The average absolute offdiagonal residual is then equal to 0,030 , which signifies a good fit. The three-factor-solution is given in Table 3.

Table 3 shows that Factor 1 has high to moderate loadings on seven of the subscores of the AQ. The seven subscores with substantial loadings represent 35 items dealing with concentration ability. Factor 1 was therefore identified as Concentration Ability. Factor 2 has high to moderate loadings on six of the subscores. These subscores represent 21 items dealing with arousal. Factor 2 was therefore identified as Arousal. Factor 3 has high to moderate loadings on two subscores dealing with distractibility, and a moderate loading on one dealing with arousal (subscore 7). Distractibility and Arousal are thus lowly correlated with one another. Factor 3 represents 13 items dealing with distractibility and four items $(26,28,29$ and 33) dealing with arousal. It was accordingly identified as Distractibility.

TABLE 3

ROTATED FACTOR MATRIX OF ATTENTION QUESTIONNAIRE (DIRECT OBLIMIN)

\begin{tabular}{|c|c|c|c|c|c|}
\hline Variables & & Factor 1 & Factor 2 & Factor 3 & $\mathbf{h}^{2}{ }_{\mathrm{j}}$ \\
\hline $\begin{array}{l}\text { Subscore 2: Items } 1^{*} \text {, } \\
4,12^{*}, 28^{*}, 30^{*}, 31 \text {, } \\
39^{*}, 58^{*}, 59^{*}, 62^{*} \text { and } \\
64^{*}\end{array}$ & 11 & 0,700 & $-0,382$ & 0,057 & 0,667 \\
\hline $\begin{array}{l}\text { Subscore } 4 \text { : Items } 16 \text {, } \\
40,44 \text { and } 56^{*}\end{array}$ & 11 & 0,544 & $-0,116$ & $-0,249$ & 0,502 \\
\hline $\begin{array}{l}\text { Subscore } 3 \text { : Items } 11^{*} \text {, } \\
18,20,21,34^{*}, 35,43 \text {, } \\
45,60,65^{*} \text { and } 72\end{array}$ & 2 & 0,525 & 0,047 & 0,052 & 0,255 \\
\hline $\begin{array}{l}\text { Subscore 11: Items } 17 \\
\text { and } 22\end{array}$ & 2 & 0,401 & $-0,024$ & $-0,166$ & 0,243 \\
\hline $\begin{array}{l}\text { Subscore 12: Items } 13 \\
\text { and } 14\end{array}$ & 4 & 0,393 & 0,071 & $-0,145$ & 0,211 \\
\hline $\begin{array}{l}\text { Subscore 13: Items 15, } \\
32,57 \text { and } 66\end{array}$ & 1 & 0,322 & 0,082 & 0,061 & 0,095 * \\
\hline Subscore 16: Item 68 & 3 & 0,143 & 0,046 & $-0,126$ & $0,047^{*}$ \\
\hline $\begin{array}{l}\text { Subscore 10: Items } \\
19^{*}, 41,42\end{array}$ & 5 & 0,124 & 0,627 & 0,007 & 0,390 \\
\hline $\begin{array}{l}\text { Subscore } 6 \text { : Items } 46 \text {, } \\
47,48,52 \text { and } 67\end{array}$ & 4 & $-0,083$ & 0,431 & $-0,003$ & 0,201 \\
\hline $\begin{array}{l}\text { Subscore 9: Items } 61 \text {, } \\
63,69 \text { and } 70\end{array}$ & 4 & $-0,164$ & 0,426 & 0,351 & 0,464 \\
\hline $\begin{array}{l}\text { Subscore } 7 \text { : Items } 26 \text {, } \\
28,29 \text { and } 33\end{array}$ & 2 & 0,123 & 0,424 & $-0,060$ & 0,178 \\
\hline $\begin{array}{l}\text { Subscore 8: Items } 49 \\
\text { and } 51\end{array}$ & 4 & $-0,189$ & 0,404 & 0,110 & 0,267 \\
\hline $\begin{array}{l}\text { Subscore 5: Items 36, } \\
37,38 \text { and } 71\end{array}$ & 2 & $-0,055$ & 0,307 & 0,065 & $0,118^{*}$ \\
\hline $\begin{array}{l}\text { Subscore 15: Items } 50 \\
\text { and } 53\end{array}$ & 10 & 0,066 & 0,176 & 0,790 & 0,685 \\
\hline $\begin{array}{l}\text { Subscore 1: Items } 2 \text {, } \\
3,5,6,7,8,9,10,24 \\
\text { and } 25\end{array}$ & 3 & 0,029 & $-0,040$ & 0,538 & 0,270 \\
\hline $\begin{array}{l}\text { Subscore 14: Items } 27, \\
54 \text { and } 55\end{array}$ & & & & & \\
\hline Number of items & 72 & 35 & 21 & 13 & \\
\hline
\end{tabular}

The intercorrelations of the factors are given in Table 4 .

TABLE 4

INTERCORRELATIONS OF FACTORS

\begin{tabular}{lccc}
\hline & & & \\
VARIABLES & FACTOR 1 & FACTOR 2 & FACTOR 3 \\
\hline FACTOR 1 & 1,000 & $-0,126^{* *}$ & $-0,372^{* *}$ \\
FACTOR 2 & $-0,126^{* *}$ & 1,000 & $0,241^{* *}$ \\
FACTOR 3 & $-0,372^{* *}$ & $0,241^{* *}$ & 1,000 \\
\hline
\end{tabular}

Note.

Factor $1=$ Concentration Ability

Factor $2=$ Arousal

Factor 3 = Distractibility

${ }^{* *}$ Correlation significant at 0,01 level (2-tailed)

From Table 4 it is clear that Concentration Ability is negatively correlated with both Arousal and Distractibility. Although both of these correlations are statistically significant $(\mathrm{p}<0,01)$ they are quite low. Arousal and Distractibility are positively correlated $(\mathrm{r}=0,241 ; \mathrm{p}<0,01)$, but the correlation is very low. 
Next, separate scales were formed in respect of the three factors, and subjected to item analysis. The item statistics in respect of Scale I (Concentration Ability) are given in Table 5.

Table 5 shows that nine items were rejected because their indices of reliability were too low. The rejected items had indices that ranged from 0,104 to 0,334 . The indices of reliability of the remaining 29 items ranged from 0,467 to 0,938 with a mean of 0,671 . The mean of the item means was 4,344 which is slightly above average, judged on a seven-point scale. The mean of the item standard deviations was 1,368 , signifying a wide range of scores. The mean of the item-test correlations was 0,490 , which indicates a high internal consistency in respect of the scale. This is supported by the Cronbach alpha reliability coefficient of 0,886 .

The item statistics in respect of Scale II (Arousal) are given in Table 6.

From Table 6 it is clear that no items were rejected. All their indices of reliability were acceptable. Their values ranged from 0,380 to 0,946 with a mean of 0,652 . The mean of the item

Table 5

ITEM STATISTICS IN RESPECT OF SCALE I OF THE AQ: CONCENTRATION ABILITY

\begin{tabular}{|c|c|c|c|c|c|c|}
\hline ITEM & DESCRIPTION OF ITEM & $\mathbf{N}$ & $\begin{array}{l}\text { Mean of } \\
\text { item } \\
\text { (M) }\end{array}$ & $\begin{array}{l}\text { Standard } \\
\text { deviation } \\
\text { of item } \\
\text { (SD) }\end{array}$ & $\begin{array}{c}\text { Item-test } \\
\text { correlation } \\
\quad\left(\mathbf{r}_{\mathrm{gx}}\right)\end{array}$ & $\begin{array}{c}\text { Index of } \\
\text { reliability } \\
\text { of item } \\
\left(\mathbf{r}_{\mathrm{gx}} \mathbf{s}_{\mathrm{g}}\right)\end{array}$ \\
\hline${ }^{*} \mathrm{Q} 1$ & Ability to concentrate when doing boring work & 1577 & 3,126 & 1,391 & 0,454 & 0,631 \\
\hline Q4 & Ability to concentrate when worried & 1577 & 3,587 & 1,490 & 0,462 & 0,688 \\
\hline${ }^{*} \mathrm{Q} 11$ & Ability to concentrate if you have to switch from one task to another & 1577 & 4,771 & 1,500 & 0,443 & 0,664 \\
\hline${ }^{*} \mathrm{Q} 12$ & Thoughts interfere with concentration & 1577 & 3,406 & 1,385 & 0,603 & 0,835 \\
\hline Q13 & Ability to isolate from surroundings when studying & 1577 & 4,894 & 1,292 & 0,475 & 0,614 \\
\hline Q14 & Ability to isolate from surroundings when writing a paper & 1577 & 5,119 & 1,248 & 0,374 & 0,467 \\
\hline Q15 & Ability to shut off from the world when reading an absorbing book & 1577 & 5,445 & 1,396 & 0,221 & $0,309^{* *}$ \\
\hline Q16 & Ability to pay attention to one specific issue for a long period of time & 1577 & 4,630 & 1,348 & 0,578 & 0,778 \\
\hline Q17 & Ability to plan ahead and pay attention to fine detail & 1577 & 4,866 & 1,376 & 0,442 & 0,609 \\
\hline Q18 & Ability to follow a long and involved logical argument & 1577 & 5,179 & 1,259 & 0,432 & 0,544 \\
\hline *Q19 & Ability to give continuous attention if volume of information is very large & 1577 & 4,277 & 1,233 & 0,084 & 0,104 * * \\
\hline Q20 & Ability to pay continuous attention to a rapid flow of information & 1577 & 4,424 & 1,257 & 0,480 & 0,603 \\
\hline Q21 & Ability to predict the outcome of a complex action & 1577 & 4,814 & 1,045 & 0,320 & 0,334 * * \\
\hline Q22 & Ability to plan fine detail of a complex action in advance & 1577 & 4,679 & 1,157 & 0,414 & 0,479 \\
\hline Q23 & Ability to return full attention to something after a short interruption & 1577 & 5,165 & 1,251 & 0,483 & 0,604 \\
\hline *Q30 & Thoughts wander while listening to a speaker & 1577 & 3,587 & 1,417 & 0,547 & 0,775 \\
\hline Q31 & Ability to listen intently to a lecture from beginning to end & 1577 & 4,491 & 1,293 & 0,608 & 0,786 \\
\hline Q32 & Ability to read a newspaper in a busy restaurant & 1577 & 5,303 & 1,461 & 0,390 & 0,570 \\
\hline *Q34 & Concentration ability diminishes if subject matter is very complex & 1577 & 4,222 & 1,462 & 0,581 & 0,849 \\
\hline Q35 & Ability to concentrate if you have little time to finish the task & 1577 & 4,523 & 1,629 & 0,357 & 0,581 \\
\hline${ }^{*} \mathrm{Q} 39$ & Thoughts wander when you are trying to concentrate & 1577 & 3,982 & 1,429 & 0,657 & 0,938 \\
\hline Q40 & Ability to concentrate for long periods of time & 1577 & 4,384 & 1,382 & 0,651 & 0,899 \\
\hline Q41 & Ability to concentrate on more than one thing at the same time & 1577 & 4,065 & 1,373 & 0,128 & 0,175 ** \\
\hline Q42 & How easy is it for you to start a new task which requires concentration? & 1577 & 4,584 & 1,539 & 0,130 & $0,199 * *$ \\
\hline Q43 & Ability to concentrate if the work is very difficult & 1577 & 4,663 & 1,311 & 0,522 & 0,684 \\
\hline Q44 & How long can you concentrate continuously? & 1577 & 3,459 & 1,389 & 0,477 & 0,663 \\
\hline Q45 & How long does it take to pay full attention to speaker who is explaining a complex issue? & 1577 & 5,120 & 1,300 & 0,468 & 0,609 \\
\hline${ }^{*} \mathrm{Q} 56$ & How tiring do you find it to concentrate for long periods of time? & 1577 & 3,419 & 1,344 & 0,551 & 0,741 \\
\hline Q57 & To what extent is your level of attention heightened during an interesting lecture? & 1577 & 6,157 & 0,887 & 0,188 & $0,167 *$ * \\
\hline *Q58 & How often do you miss vital information during a boring lecture? & 1577 & 3,614 & 1,438 & 0,483 & 0,694 \\
\hline${ }^{*}$ Q59 & Ability to concentrate if level of complexity of material is very low & 1577 & 4,377 & 1,641 & 0,153 & 0,250 * * \\
\hline Q60 & How fast can you process complex information? & 1577 & 4,739 & 1,062 & 0,464 & 0,492 \\
\hline${ }^{*} \mathrm{Q} 62$ & Ability to listen intently to a lecture that is presented entirely orally & 1577 & 4,114 & 1,403 & 0,461 & 0,647 \\
\hline${ }^{*} \mathrm{Q} 64$ & How often do you forget what you were on the point of doing? & 1577 & 4,101 & 1,458 & 0,461 & 0,672 \\
\hline Q65 & Ability to give continuous attention if material is highly abstract & 1577 & 3,956 & 1,231 & 0,441 & 0,543 \\
\hline${ }^{*} \mathrm{Q} 66$ & $\begin{array}{l}\text { To what extent do you become shut off from the world around you when you are trying to } \\
\text { solve a challenging problem? }\end{array}$ & 1577 & 5,186 & 1,202 & 0,228 & 0,274 * * \\
\hline Q68 & To what extent does your ability to concentrate improve over time? & 1577 & 4,608 & 1,325 & 0,184 & 0,244 * * \\
\hline${ }^{*} \mathrm{Q} 72$ & How does fear of failure disturb your concentration? & 1577 & 4,469 & 1,706 & 0,461 & 0,787 \\
\hline
\end{tabular}


means was 4,785 which is somewhat above average, judged on a seven-point scale. The mean of the item standard deviations was 1,562 , which indicates a wide distribution of scores. The mean of the item-test correlations was 0,415, which indicates a high internal consistency in respect of the scale. This is supported by a moderate alpha reliability coefficient of 0,757 .

Table 6

Item STATISTICS IN RESPECT OF SCLAE II OF THE AQ: ARousal

\begin{tabular}{|c|c|c|c|c|c|c|}
\hline ITEM & DESCRIPTION OF ITEM & $\mathbf{N}$ & $\begin{array}{l}\text { Mean } \\
\text { of } \\
\text { item } \\
(\mathrm{M})\end{array}$ & $\begin{array}{l}\text { Standard } \\
\text { deviation } \\
\text { of item } \\
\text { (SD) }\end{array}$ & $\begin{array}{c}\text { Item-test } \\
\text { correlation } \\
\quad\left(\mathbf{r}_{\mathrm{gx}}\right)\end{array}$ & $\begin{array}{c}\text { Index of } \\
\text { reliability } \\
\text { of item } \\
\left(\mathbf{r}_{\mathrm{gx}} \mathbf{s}_{\mathrm{g}}\right)\end{array}$ \\
\hline $\mathrm{Q}_{26}$ & $\begin{array}{l}\text { To what extent would the incessant barking of dogs in the vicinity distract you if you are concentrating } \\
\text { intensively on a problem? }\end{array}$ & 1577 & 4,524 & 1,819 & 0,479 & 0,872 \\
\hline $\mathrm{Q}_{28}$ & $\begin{array}{l}\text { How much would it distract your attention if an invigilator came and stood near you while you are } \\
\text { writing an examination? }\end{array}$ & 1577 & 4,774 & 1,970 & 0,480 & 0,946 \\
\hline $\mathrm{Q}_{29}$ & $\begin{array}{l}\text { To what extent would the constant ringing of a telephone in another room distract your attention } \\
\text { while you are studying? }\end{array}$ & 1577 & 5,247 & 1,538 & 0,521 & 0,801 \\
\hline $\mathrm{Q}_{33}$ & To what extent is your attention disturbed if someone giggles in the class? & 1577 & 4,011 & 1,629 & 0,435 & 0,708 \\
\hline $\mathrm{Q}_{36}$ & To what extent is your concentration disturbed if you are feeling cold? & 1577 & 4,197 & 1,587 & 0,443 & 0,703 \\
\hline $\mathrm{Q}_{37}$ & To what extent is your concentration disturbed if you are feeling hungry? & 1577 & 4,749 & 1,557 & 0,451 & 0,703 \\
\hline $\mathrm{Q}_{38}$ & To what extent is your concentration disturbed if you are feeling too warm? & 1577 & 4,424 & 1,539 & 0,431 & 0,663 \\
\hline $\mathrm{Q}_{46}$ & How strongly will you react to a shrill sound if it is presented to you repeatedly? & 1577 & 5,013 & 1,399 & 0,350 & 0,490 \\
\hline $\mathrm{Q}_{47}$ & How readily will you be alerted by an unfamiliar noise while you are reading a gripping story? & 1577 & 4,625 & 1,707 & 0,457 & 0,781 \\
\hline $\mathrm{Q}_{48}$ & How easily will you be alerted by the sound of breaking glass amidst a high level of background noise? & 1577 & 5,247 & 1,393 & 0,336 & 0,468 \\
\hline $\mathrm{Q}_{49}$ & How easily will you be aroused from your sleep by a scream close to your bedroom? & 1577 & 5,091 & 1,862 & 0,386 & 0,718 \\
\hline $\mathrm{Q}_{50}$ & $\begin{array}{l}\text { How strongly will you react to a loud but familiar sound while you are quietly relaxing with an } \\
\text { interesting book? }\end{array}$ & 1577 & 3,923 & 1,678 & 0,431 & 0,723 \\
\hline $\mathrm{Q}_{51}$ & How easily will you be aroused from your sleep by the sound of a car braking heavily? & 1577 & 3,606 & 1,886 & 0,469 & 0,885 \\
\hline $\mathrm{Q}_{52}$ & How easily will you be alerted by an unfamiliar sound while you are reading and it is absolutely quiet? & 1577 & 5,633 & 1,363 & 0,479 & 0,653 \\
\hline $\mathrm{Q}_{53}$ & How strongly will you react to a shrill sound if you know exactly when it will be activated? & 1577 & 3,869 & 1,816 & 0,295 & 0,536 \\
\hline $\mathrm{Q}_{61}$ & To what extent is your ability to concentrate facilitated by change and variety in a lecture? & 1577 & 5,138 & 1,294 & 0,314 & 0,406 \\
\hline $\mathrm{Q}_{63}$ & To what extent does humour in a lecture facilitate your concentration? & 1577 & 5,928 & 1,224 & 0,311 & 0,380 \\
\hline $\mathrm{Q}_{67}$ & How strongly will you react to a shrill sound if it is accidentally activated? & 1577 & 5,817 & 1,192 & 0,470 & 0,560 \\
\hline $\mathrm{Q}_{69}$ & To what extent does hostility on the part of a lecturer inhibit (disturb) your ability to concentrate? & 1577 & 4,713 & 1,391 & 0,451 & 0,628 \\
\hline $\mathrm{Q}_{70}$ & To what extent does regular rest pauses facilitate your ability to concentrate? & 1577 & 5,053 & 1,470 & 0,314 & 0,461 \\
\hline $\mathrm{Q}_{71}$ & To what extent does sleep deprivation disturb your ability to concentrate? & 1577 & 4,893 & 1,492 & 0,403 & 0,601 \\
\hline
\end{tabular}

Note.

Cronbach alpha $=0,757$

Number of items $=21$

No items were reflected

TABLE 7

ITEM STATISTICS IN RESPECT OF SCALE III OF THE AQ: DISTRACTIBIIITY

\begin{tabular}{|c|c|c|c|c|c|c|}
\hline ITEM & DESCRIPTION OF ITEM & $\mathbf{N}$ & $\begin{array}{c}\text { Mean } \\
\text { of } \\
\text { item } \\
(\mathrm{M})\end{array}$ & $\begin{array}{l}\text { Standard } \\
\text { deviation } \\
\text { of item } \\
\text { (SD) }\end{array}$ & $\begin{array}{l}\text { Item-test } \\
\text { correlation } \\
\quad\left(\mathbf{r}_{\mathrm{gx}}\right)\end{array}$ & $\begin{array}{l}\text { Index of } \\
\text { reliability of } \\
\text { item }\left(r_{g x} s_{g}\right)\end{array}$ \\
\hline${ }^{*} \mathrm{Q}_{2}$ & How well can you concentrate if something in the background is distracting you? & 1577 & 3,928 & 1,436 & 0,585 & 0,841 \\
\hline $\mathrm{Q}_{3}$ & $\begin{array}{l}\text { To what extent will it hamper your ability to concentrate if you have to study in a group with } \\
\text { other people? }\end{array}$ & 1577 & 3,898 & 1,664 & 0,333 & 0,554 * * \\
\hline $\mathrm{Q}_{5}$ & How quiet must the environment be in order for you to study effectively? & 1577 & 5,062 & 1,426 & 0,727 & 1,037 \\
\hline $\mathrm{Q}_{6}$ & How badly will music in your immediate environment disturb your concentration? & 1577 & 4,024 & 1,825 & 0,711 & 1,298 \\
\hline $\mathrm{Q}_{7}$ & How badly will noise in your immediate environment disturb your concentration? & 1577 & 4,938 & 1,471 & 0,752 & 1,106 \\
\hline $\mathrm{Q}_{8}$ & How badly will chatter in your immediate environment disturb your concentration? & 1577 & 5,015 & 1,435 & 0,697 & 1,000 \\
\hline $\mathrm{Q}_{9}$ & To what extent are you dependent on absolute silence if you want to concentrate? & 1577 & 4,635 & 1,611 & 0,786 & 1,267 \\
\hline $\mathrm{Q}_{10}$ & To what extent will people moving around in your immediate environment distract your attention? & 1577 & 4,130 & 1,543 & 0,563 & 0,868 \\
\hline $\mathrm{Q}_{24}$ & $\begin{array}{l}\text { To what extent would it distract you if other people in the room spoke softly while you are } \\
\text { studying? }\end{array}$ & 1577 & 4,339 & 1,758 & 0,634 & 1,114 \\
\hline $\mathrm{Q}_{25}$ & To what extent would the noise of a TV in an adjacent room distract you from your studies? & 1577 & 4,476 & 1,702 & 0,700 & 1,192 \\
\hline * $\mathrm{Q}_{27}$ & How easily can you follow a discussion on radio whilst studying? & 1577 & 4,805 & 1,649 & 0,272 & $0,449^{* *}$ \\
\hline${ }^{*} \mathrm{Q}_{54}$ & How easy or difficult do you find it to do calculations while you are listening to a news broadcast? & 1577 & 3,917 & 1,719 & 0,291 & $0,500 * *$ \\
\hline${ }^{*} \mathrm{Q}_{55}$ & How easily will you adapt to loud music whilst trying to solve a problem? & 1577 & 4,089 & 1,632 & 0,555 & 0,906 \\
\hline
\end{tabular}

Note.

Cronbach alpha $=0,863$.

Number of items $=10$

* = Reflected

** $=$ Items rejected 
The item statistics in respect of Scale III (Distractibility) are given in Table 7.

Table 7 shows that three items were rejected because their indices of reliability were too low. The rejected items had indices that ranged from 0,449 to 0,554 . The indices of reliability of the remaining 10 items ranged from 0,841 to 1,298 with a mean of 1,063 . The mean of the item means was 4,464 which is slightly above average, judged on a seven-point scale. The mean of the item standard deviations was 1,584 , which signifies a wide range of scores. The mean of the item-test correlations was 0,671 which indicates a high internal consistency in respect of the scale. This is supported by a Cronbach alpha reliability coefficient of 0,863 .

From the foregoing it is clear that two of the scales of the AQ have acceptable reliabilities. The Arousal scale, however, will have to be extended to increase its reliability. Even if parallel items are added its reliability can easily be increased. According to the Spearman-Brown Formula (Brown, 1910) the reliability of the scale will increase from 0,757 to 0,817 if the number of items is increased to 30. Furthermore, the 12 rejected items would have to be revised or replaced. Special attention will have to be paid to the content validity of the Distractibility scale as all the items deal with needing silence when performing a task.

In order to determine the common factor structure of the $\mathrm{AQ}$ and the LCI the two instruments were subjected to a multiple battery factor analysis (MBFA). As a first step in the analysis, the three measures of the LCI and the three scales of the AQ were intercorrelated. The matrix of intercorrelations of the various measures is given in Table 8 .

TABLE 8

Matrix OF INTERCorrelations OF THE MEASURES OF THE AQ AND LCI

\begin{tabular}{|c|c|c|c|c|c|c|}
\hline Variables & $\begin{array}{c}\text { Auton- } \\
\text { omy }\end{array}$ & $\begin{array}{c}\text { External } \\
\text { control }\end{array}$ & $\begin{array}{c}\text { Internal } \\
\text { control }\end{array}$ & $\begin{array}{l}\text { Concen- } \\
\text { tration } \\
\text { ability }\end{array}$ & $\begin{array}{l}\text { Distract- } \\
\text { ibility }\end{array}$ & Arousal \\
\hline Autonomy & 1,000 & $-0,369$ ** & 0,508 * * & $0,520^{* *}$ & $-0,225^{\text {* * }}$ & $-0,092^{* *}$ \\
\hline $\begin{array}{l}\text { External } \\
\text { control }\end{array}$ & $-0,369$ * * & 1,000 & $-0,154$ * * & $-0,433$ * * & 0,198 * * & 0,342 ** \\
\hline $\begin{array}{l}\text { Internal } \\
\text { control }\end{array}$ & 0,508 ** & $-0,154^{* *}$ & 1,000 & 0,254 * * & $0,083^{* *}$ & $0,154^{* *}$ \\
\hline $\begin{array}{l}\text { Concentration } \\
\text { ability }\end{array}$ & $0,520^{* *}$ & $-0,433$ ** & $0,254^{* *}$ & 1,000 & $-0,326^{* *}$ & $-0,440^{* *}$ \\
\hline Distractibilty & $-0,225^{* *}$ & $0,198 * *$ & 0,083 * * & $-0,326^{* *}$ & 1,000 & 0,407 * * \\
\hline Arousal & $-0,092 * *$ & 0,342 ** & 0,154 * * & $-0,440$ ** & 0,407 * * & 1,000 \\
\hline
\end{tabular}

Note.

$\mathrm{N}=1286$

**Significant at 0,01 level

MBFA uses the cross-correlations between the batteries of tests included in the analysis to overcome the confounding of covariation within batteries and covariation between batteries (Finch \& West, 1997, p. 470).

From Table 8 it is clear that all the intercorrelations in the matrix are statistically significant.

To determine the number of common factors to extract a statistical test was done (Browne, 1980; Cudeck, 1991). The results of the test are given in Table 9.

Table 9 indicates that there are two statistically significant factors. The upper-tail probability was $<0,001$ in respect of both factors. The Tucker-Lewis reliability coefficient was equal to 0,949 , which indicates a very good "quality of representation of (the) interrelations among (the) attributes in the battery" that was subjected to maximum likelihood factor analysis (Tucker \& Lewis, 1973, p. 1).
TABLE 9

GOODNESS OF FIT STATISTICS: ATTENTION QUESTIONNAIRE AND LCI

\begin{tabular}{lrc}
\hline Variables & 1 Factor & 2 Factors \\
\hline Test statistic & 239,960 & 41,299 \\
Degrees of freedom & 4,000 & 1,000 \\
Upper-tail probability & $<0,001$ & $<0,001$ \\
Tucker-Lewis reliability coefficient & 0,696 & 0,949 \\
Rescaled Akaike information criterion & 0,213 & 0,063 \\
Rescaled Akaike for saturated model & 0,033 & 0,033 \\
Average absolute off-diagonal residual & 0,115 & 0,055 \\
\hline
\end{tabular}

The Akaike Information Criterion is considerably smaller for two factors than for one factor, which suggests a reasonable fit of the model to the data. This is also supported by the average absolute off-diagonal residual of 0,055 .

The obtained factors were rotated to simple structure by means of a Direct Quartimin rotation. The rotated factor matrix is given in Table 10.

\section{Table 10}

FACTOR MATRIX: ATTENTION QUESTIONNAIRE AND LOCUS OF CONTROL INVENTORY

\begin{tabular}{lcc}
\hline Variables & Factor $\mathbf{1}$ & Factor 2 \\
\hline LCI: Autonomy & $-0,298$ & 0,614 \\
LCI: External Control & 0,580 & $-0,144$ \\
LCI: Internal Control & 0,175 & 0,590 \\
AQ: Concentration Ability & $-0,494$ & 0,496 \\
AQ: Arousal & 0,436 & $-0,019$ \\
AQ: Distractibility & 0,622 & 0,222 \\
\hline Note. & &
\end{tabular}

Direct Quartimin rotation

FACTOR CORRELATIONS

\begin{tabular}{ccc}
\hline Factor & 1 & 2 \\
\hline 1 & 1,000 & \\
2 & $-0,169$ & 1,000 \\
\hline
\end{tabular}

Both factors are well determined with three or more high loadings. Factor 1 has high to moderate loadings on External Control $(0,580)$, Concentration Ability $(-0,494)$, Arousal $(0,436)$, and Distractibility $(0,622)$. Persons who are high on External Control are therefore easily aroused and distracted, and have difficulty in concentrating. Factor 2 has high to moderate loadings on Autonomy $(0,614)$, Internal Control $(0,590)$ and Concentration Ability $(0,496)$. Persons who are high on Autonomy and Internal Control can therefore concentrate with ease. From the factor correlations it is clear that Factors 1 and 2 are virtually uncorrelated $(-0,169)$.

\section{DISCUSSION}

As far as the principal objective of the study is concerned the analysis yielded three well-defined factors that were identified as Concentration Ability, Arousal and Distractibility. Three scales were formed, corresponding to the three factors that were obtained. The scales yielded reliabilities of $0,886,0,757$ and 0,863 respectively. Altogether 12 items were rejected on metrical grounds and need to be revised or replaced with more appropriate ones. In particular more items dealing with arousal are required to increase the reliability of the Arousal Scale. From a content validity point of view the Distractibility Scale needs to be extended, as all the items currently included in the scale deal with the issue of requiring silence when performing a task. 
As far as the corollary of the study is concerned, two common factors were obtained when the AQ and LCI were subjected to a multiple battery factor analysis. The first factor had high positive loadings on External Control, Distractibility and Arousal, and a negative loading on Concentration Ability. The second factor had high positive loadings on Autonomy, Internal Control and Concentration Ability. The two common factors that were obtained are virtually uncorrelated with one another $(r=-0,169$; $\mathrm{p}<0,01)$.

Picton et al. (1978, p. 446) linked human attention to the evoked potential of the brain. They maintained that "attention has its most definite neurophysiological components that occur later than 50 msec after stimulus onset". There is thus empirical evidence that concentration ability has a neurological basis. By association this would include autonomy and internal control which are positively correlated with concentration ability.

The construct validity of the $\mathrm{AQ}$ has been reasonably well established, but much more work is necessary to establish the convergent validity of the instrument.

\section{ACKNOWLEDGEMENTS}

I hereby wish to thank Adam Martin and Anneli Hardy of the Statistical Consultation Service of the University of Johannesburg for all the hours of computational work done for me. I value it very highly.

A special word of thanks to Annetjie Boshoff for the typing of the manuscript at short notice.

\section{REFERENCES}

Bornstein, M.H. (1990). Attention in infancy and the prediction of cognitive capacities in childhood. In J.T. Enns (Ed.). The development of attention: Research and theory (pp. 3-19). North-Holland: Elsevier Science Publishing Company, Inc.

Brown, W. (1910). Some experimental results in the correlation of mental abilities. British Journal of Psychology, 3, 296-322.

Browne, M.W. (1980). Factor analysis of multiple batteries by maximum likelihood. British Journal of Mathematical and Statistical Psychology, 33, 184-199.

Cudeck, R. (1991). Program: MBFA: Maximum likelihood solution for multiple battery factor analysis. Department of Psychology, University of Southern California, Los Angeles.

Damrad-Frye, R. \& Laird, J.D. (1989). The experience of boredom: The role of the self-perception of attention. Journal of Personality and Social Psychology, 57(2), 315-320.

Davidoff, L.L. (1987). Introduction to psychology (3 ${ }^{\text {rd }}$ ed). New York: McGraw-Hill.

De W Vos, S.J. \& Schepers, J.M. (1993). Kognitiewe en persoonlikheidskorrelate van aandaggewing. Journal of Industrial Psychology, 19(3), 23-29.

Diehl, M., Semegon, A.B. \& Schwarzer, R. (2006). Assessing attention control in goal pursuit: A component of dispositional self-regulation. Journal of Personality Assessment, 86(3), 306-317.

Eysenck, H.J. (1967). The biological basis of personality. Springfield: Charles C. Thomas.

Finch, J.F. \& West, S.G. (1997). The investigation of personality structure: Statistical models. Journal of Research in Personality, $31,439-485$.
Greenglass, E. (2002). Proactive coping. In Frydenberg, E. (Ed.). Beyond coping: Meeting goals, vision and challenges (pp. 37-62). London: Oxford University Press.

Grossman, S.P. (1973). Essentials of physiological psychology. New York: Wiley \& Sons.

Harkins, S. \& Geen, R.G. (1975). Discriminability and criterion differences between extraverts and introverts during vigilance. Journal of Research in Personality, 9, 335-340.

Hendriks, A.A.J., Hofstee, W.K.B. \& De Raad, B. (1999). The Five-Factor Personality Inventory (FFPI). Personality-andIndividual-Differences, 27(2), 307-325.

Howard, D.V. (1983). Cognitive psychology. New York: Macmillan.

Kaiser, H.F. (1961). A note on Guttman's lower bound for the number of common factors. British Journal of Statistical Psychology, 14(1), 1.

Matthews, K.A., Carver, C.S. \& Scheier, M.F. (1982). Focus of attention and awareness of bodily sensations. In G. Underwood (Ed.). Aspects of consciousness, vol. 3 (pp. 165-197). New York: Academic Press.

Neisser, U. (1976). Cognition and reality: Principles and implications of cognitive psychology. San Francisco: Freeman and Company.

Picton, T.W., Campbell, K.B., Baribeau-Braun, J. \& Proulx, G.B. (1978). The neurophysiology of human attention. In J. Requin (Ed.). Attention and performance, VII (pp. 429-467). Mahwah, N.J.: Erlbaum.

Rothbart, M.K., Posner, M.I. \& Boylan, A. (1990). Regulatory mechanisms in infant development. In J.T. Enns (Ed.). The development of attention: Research and theory (pp. 47-66). North-Holland: Elsevier Science Publishing Company, Inc..

Rusinova, V. (1990). Psychological regulation of tension in work. Studia Psychologica, 32, 163-170.

Schafer, E.W.P. (1979). Cognitive neural adaptability: a biological basis for individual differences in intelligence. Psychophysiology, 16, 199.

Schafer, E.W.P. (1982). Neural adaptability: a biological determinant of behavioral intelligence. International Journal of Neuroscience, 17, 183-191.

Schwarzer, R., Diehl, M. \& Schmitz, G.S. (1999). Self-Regulation Scale. Retrieved15 August, 2006 from http//www.fu-berlin. de/gesund/skalen.

Schwarzer, R. \& Jerusalem, M. (1995). Generalized Self-Efficacy scale. In Weinman, J., Wright, S. \& Johnston, M. (Eds.). Measures in health psychology: A user's potfolio. Causal and control beliefs (pp. 35-37). Windsor, England: NELSON.

Schepers, J.M. (1992). Toetskonstruksie: Teorie en praktyk. Rand Afrikaans University. Johannesburg: RAU-Press.

Schepers, J.M.,Stuart, A.D. \& Todd, A.E. (1999). Electrophysiological concomitants of psychometric intelligence. South African Journal of Psychology, 29(3), 138-144.

Schepers, J.M. (2002). Construction of a computerised information-processing test battery. SA Journal of Industrial Psychology, 28(2), 55-66.

Schepers, J.M. (2004). The power of multiple battery factor analysis in coping with the effects of differential skewness of variables. Special edition of SA Journal of Industrial Psychology, 30(4), 78-81.

Schepers, J.M., Gropp, L. \& Geldenhuys, D.J. (2006). The factor structure, metrical properties, and convergent validity of the third edition (1999) of the Locus of Control Inventory. SA Journal of Industrial Psychology, 32(2), 1-8.

Tucker, L.R. \& Lewis, C. (1973). A reliability coefficient for maximum likelihood factor analysis. Psychometrika, 38(1), $1-10$.

Wood, R.E. \& Locke, E.A. (1987). The relation of self-efficacy and grade goals to academic performance. Educational and Psychological Measures, 47, 1013-1024. 